\title{
Impact of Intellectual Property Infringement Lawsuits in the U.S. on Firm Value
}

\author{
WONSEOK WOO ${ }^{* *}$
}

This paper investigates the economic impact of intellectual property infringement lawsuits on the values of both the plaintiff and the defendant firms in the information technology industry. Event study methodology is used to investigate the effect of the litigation on the stock market returns around the date of commencement as well as the date of termination. Our results suggest that the news of intellectual property infringement lawsuits was unfavorably accepted in the stock market for the defendants. On the other hand, abnormal returns for plaintiff firms around lawsuit commencement date were significantly positive, while those at termination date were not positive at a statistically significant level. We also found that firms in other technology sectors have been influenced more by the intellectual property infringement lawsuits than those in computer hardware \& peripheral sectors.

Kejuords: intellectual property, patent lawsuits, firm value, IT industry, event study

I would like to thank Prof S. Chosh (College of Law) and Edward Tirpak (University latent Otficer) for their comments regarding this paper. An earlier version of this paper was published in the proceedings of ICIS 1996. I would like to thank the conference attendees for comments that howe helped (1) considerably improve the paper and Prof Amit Dutta of GMU for his encouragement on an earlier version of the paper.

${ }^{* *}$ Wonseok Woo, Assistant Professor, Division of International Studies, Ewha Womans l nniversity, Seodaemun-gu, Seoul, 120-750, South Korea; Tel: 82-2-3277-4455; E-mail: wwoolu cwhatakikr 


\section{INTRODUCTION}

I

ntellectual property infringement lawsuits in the Information Technology (IT) industry have increased substantially in recent years. The number of patents issued for all the utility and design categories has risen from approximately 55,000 in 1979 to approximately 144,000 in 1998.1 Patents drive 60 percent of current intellectual property litigation, while trademarks and copyrights represent another 34 percent (Pearson, Nickson and Marvel 2001). The damages awarded to patentees in such litigation are substantial, as is the cost of litigation. ${ }^{2}$ Large IT firms as Intel Corp. and AMD Corp. have spent almost $\$ 200$ million in intellectual property lawsuits during the early 90 s. $^{3}$

Litigation against companies in software, hardware, semiconductor and Internet businesses represent about 40 percent of intellectual property infringement litigation. There have been several articles in trade journals concerning the tremendous increase in the number of patents issued and also the related increase in the number of intellectual property infringement lawsuits in the information technology industry. Journalists have attributed the increase in patent lawsuits to the developments in the patent policies of the U.S. government since the early 1980s. Supreme Court decision in the early 80s that software could be patented and the creation of the Court of Appeals of the Federal Circuit in 1983 have also been cited as crucial developinents that triggered the boom in litigation relating to patents in the information technology industry (Ewert 1995). ${ }^{4}$ Many in the trade believe that big companies, faced with increasing competition and eroding margins, are using the developments in the patent laws to thwart competition from smaller competitors. A Forbes article (Rutter 1993) mentions Intel's suit against VLSI and Cyrix in this regard. Many cases have been cited in Rutter (1993) as landmark developments in the IT industry as far as patent litigations are concerned. This includes the almost $\$ 1$ billion award in favor of Polaroid in the Polaroid vs. Kodak dispute, which put Kodak out of the instant photo business, and Texas Instruments suing nine Asian companies for infringing on its DRAM (Dynamic Random Access Memory) patents.

The contribution of this study is two fold: First this study is among the first of its kind to examine the economic impact of intellectual property infringement lawsuits on information technology (IT) companies involved in terms of both commencement and termination effects. Though market analysts have suggrested that the market value of the firms fluctuate in accordance with the direction of the lawsuit proceedings', no empirical eridence of these effects have been seen. The impact on common shareholder returns is used as evidence of the effect of litigation on the value of IT firms. The use of shareholder wealth as a surrogate for firm value is justified by the observance of very low debt ratios among IT firms. Second, the study investigates factors that could affect

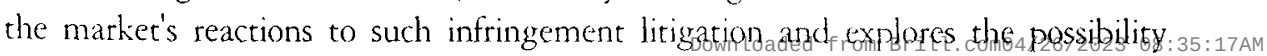


of systematic differences in the market's reactions based on the size of the firm or the IT sector to which the disputed intellectual property belongs.

\section{BACKGROUND}

Patents as a means of competitive advantage and barrier to entry have long been recognized in management literature (Porter 1980). Several articles have appeared in economic and marketing literature on various aspects of patents and patent administration. The rich variety of articles in this area emphasizes the importance of patents as a strategic tool for high technology firms. In this section we briefly discuss some of the research relating to patents. Tirole (1988) considers the purpose of patents as a means to create a temporary monopoly for the innovator in return for the efforts put forth towards the innovation. However, the ability of the inventor to benefit from the patent depends on how broad the patent is and how difficult it is for the competitors to provide a similar product without infringing on the patent (the process of imitation) (Gilbert and Shapiro 1990, and Klemperor 1990). The competitor's decision to imitate depends on the length and the breadth of the patent protection. Manfredi, Ross and David (1989) argue that the inventors disclose pre-production information in return for a patent reward resulting in the pilferage of product information by its competitors. A patent-free regime, in their view, would provide initial inventors an interval in which to profit from the innovation.

Another aspect of the patenting problem is licensing of a patent. Transfer of patented technology to another firm is always fraught with risk, especially in an environment where patent protection is uncertain (Vishwasrao 1994). Licensing contracts for innovations can vary with respect to form and size of the payments, the degree of exclusivity, and the division of rents (Gallini and Wright 199(0). The form of the contract is dependent on the superiority of a licensor's precontractual information about the economic value of the innovation and the fact that sharing this information with the licensee may facilitate imitation (Gallini and Wright 1990). In fact many of the patent litigations in the information technology industry in our study trace their origins to problems in the licensing agreements. However, the subject of patent litigation itself has not been addressed exclusively in literature. Meurer (1989) proposes a model to analyze patene licensing as part of a settement agreement to avoid litigation of the issue of patent validity. In their recent study on patent litigation Lanjouw and Schankerman (2001) test the relationship between various characteristics of patents and their owners and the likelihood that they will become involved in legal conflicts. Their work focuses on examining the determinants of patent suits but does not look at the economic or financial impact of patent-infringement lawsuits on the participant firms. To our knowledge no other work has discussed the 
subject of the effect of patent litigation on stock prices exclusively.

We find that there are very few empirical studies to support the theoretical foundations of patent economics and, to our knowledge, there is none in the information technology arena. Lerner (1994) provides an empirical analysis discussing the importance of patent scope. Shapiro and Lorne (1993) study the stock market response to changing drug patent legislation in Canada. Cockburn and Griliches (1988) study the stock market's valuation of $R \& D$ and Patents with respect to industry segments and appropriability measures. They find that the returns to a firm from investing in patent protection differ according to industry and firm specific conditions. In a similar study of imitation costs in three industries, viz. chemicals, drugs and electronics (Jaffe 1986), it is found that patented products were imitated within four years of innovation. An interesting finding of the study is that without patents it would have been difficult for the competitors in the electronics industry to imitate a new product. The reason for this is that it is quite difficult for imitators to know the procedure of producing the product newly invented. In general, the study found that patents are considered more important in the drug industry than in the other two industries. However, the imitation costs to the competitors were found to increase irrespective of the industries in the presence of a patent. In their empirical study involving the chemical, electrical and electronics industries in the U.K Smyth, Samuels and Tzoannos (1972), found that smaller firms innovate proportionately less than the larger firms and innovative activity is not related to prior profitability of the firm.

\section{RESEARCH HYPOTHESES}

This study adds to existing literature on patents by examining the economic impact of patent litigation in the information technology industry using event study methodology. Event study has been commonly employed in accounting, finance and marketing literature (Loderer and Mauer 1992, Muoghalu, Robinson and Glascock 1990, Agarwal and Kamakura 1995) and more recently in information systems literature (Dos Santos, Peffers and Mauer 1993, Loh 1993, Chatterjee, Richardson and Znud 2001, Im, Dow and Grover 2001, Subramani and Walden 2001). The rationale for employing event study methodology is that it assumes that the financial markets are at least semi-strong form efficient (Fama 1970). Market prices of securities reflect all publicly available information relevant to decermining the expected cash flows and profits to the firm. New information, if any, contained in the commencement (or termination) of a intellectual property infringement lawsuit causes the market to revise its expectations about the magnitude (or risk) of the fucure cash flows and profits and adjust the value of the firms accordingly. These adjustments are immediately witnessed 
by changes in the stock prices of the firms. The abnormal stock returns attributable to the commencement or termination of lawsuits thus form the basis of a measure of the economic impact of patent litigation.

It is evident that the market evaluates the value of a firm based on the net income the firm can generate from its tangible and intangible assets (Cockburn and Griliches 1988). R\&D efforts, intellectual property rights, goodwill, advertising and marketing skills, and human resources are some of the intangible assets that are considered important for a firm's long-term survival in its industry. Patents and copyrights (the two most important forms of intellectual property), which are the outcomes of the firm's R\&D and innovation efforts, are of significant economic importance to the firm (Tirole 1988, Porter 1980). In addition, empirical support for the economic significance of patents to firm value is available in Shapiro and Lorne (1993), and Lerner (1994). Dang, Lev and Narin (1999) found that their set of patent-related measures are closely associated with stock performance, concluding that patent attributes provide a useful tool for the analysis of valuation for technology and science-based firms.

The holder of a patent is granted monopoly rights to exploit the invention for a specified time period. In essence, patents and copyrights (to some extent, especially as applicable to computer software and literary works) are a form of reward given to a firm for its innovations. This monopoly right is threatened when a competitor infringes on the patent or copyright. A rational firm would evaluate the threat in terms of the costs and benefits of pursuing litigation. A commencement of lawsuit could convey new information to financial markets even if the markets were previously aware of the threat from a competitor.

The revaluation could be either an increase or a decrease in the market value of the firms involved. The market's reaction to the intellectual property right dispute depends on a number of factors. These factors include the probability of a judicial enforcement of the patents or copyright protection, the economic significance of the patent protection, etc. Because of the unclear nature of the intellectual property laws (Meurer 1989), the granting of a patent or copyright does not necessarily mean that said patents will be considered valid in a court of law. The probability of the validity of the patents and copyrights depends on a number of factors, such as the clarity of the law, disclosure regulations (Nordhaus 1969), information on prior art, etc (Meurer 1989). In addition, the prevailing legal environment has a significant effect on the outcome of intellectual property disputes. The application of the patent laws mar not be uniform in all courts. This flaw in the U.S. patent system has been overcome to some extent by the establishment of the U.S. Court of Appeals for patents. In addition, the government's attitude towards anti-trust regulations could also be a determining factor (some of the views expressed by industry experts on the legal issues can be found in the trade journal articles cited in the end notes). In addition, a large number of patents have been issued in the computer 
industry over a small period of time.

To the extent that an "average" reaction exists at the time of commencement, we would expect that plaintiff and defendant firms would exhibit opposite signs for the abnormal returns, i.e. if, on average, plaintiff firms gained from announcing a lawsuit, the defendant firms would lose, on average. This leads to our first hypothesis.

Hypothesis 1: On average, the initial announcements of intellectual property infringement litigation will lead to positive abnormal returns for the plaintiff firms and negative abnormal returns to the defendant firms.

The termination of litigation results in revealing the validity of the firm's sole ownership of the relevant intellectual property. Though the markets may be monitoring the progress of the litigation and updating its forecast of the firm's prospects, the termination may still contain enough new information which is unanticipated by the markets. This leads to our second hypothesis.

\section{Hypothesis 2: On average, announcement of settlement or termination of intellectual property infringement litigation will lead to positive abnormal returns for the plaintiff firms and negative abnormal returns to the defendant firms.}

These litigations have a range of outcomes at termination-withdrawn, defeated, or awards are made, patents are upheld, and/or settlement is reached. We expect that settlements or terminations that favor plaintiffs will positively affect the plaintiffs' stock prices and negarively affect defendants' stock prices at the announcements of settlement or terminations. Our next and last set of hypotheses are as follows.

Hypothesis 3a: Settlement or termination in favor of the plaintiff will lead to positive abnormal returns for the plaintiff firms.

Hypothesis 3b: Settlement or termination in favor of the plaintiff will lead to negative abnormal returns for the defendant firms.

\section{EVENT STUDY METHODOLOGY}

Event study methodology is based on the assumption of efficient capital market theory (Fama 1970). Efficient capital market theory states that the market value of the firms as reflected in their security prices fully reflect the available information. As a result, whenever new information is made available to the market, the market adjusts the firm's value to reflect the changes in the present value of the cash flow and profits resulting from the new developments Recently event 35:17Am 
study methodology is popular in examining the impact or value of IT related events based on stock price movement (Chatterjee, Richardson and Zmud 2001; Subramani and Walden 2001; Im, Dow and Grover 2001). In our case, the new information available to the market is the commencement of the intellectual property infringement litigation and later, the termination of the infringement litigation. The same methodology has been applied to study the effect of hazardous waste lawsuits by Muoghalu, Robinson, and Glascock (1990), and Wier (1983).

The Dodd and Warner (1983) methodology is used for the event study. The event in the study is the announcement of an intellectual property infringement lawsuit commencement, and subsequently the announcement of a judgment by the court or a settlement reached out of court (i.e., lawsuit termination).

It is assumed that the daily common stock returns of a company are described by the Market Model. Under this model, the normal returns on the firm's stock are described by:

$$
\mathrm{R}_{\mathrm{it}}=a_{\mathrm{i}}+\beta_{\mathrm{i}} \mathrm{Rmt}+\varepsilon_{\mathrm{it}}
$$

Where,

$$
\begin{aligned}
& R_{i t}=\text { Rate of return for the firm } i \text { on day } t \\
& R_{m t}=\text { Rate of return for the market portfolio on day } t \\
& a_{i}, \beta_{i}=\text { Estimated Parameters } \\
& \varepsilon_{i t}=\text { Error Term for firm } i \text { on day } t \text {. }
\end{aligned}
$$

Equation (1) has two components in the return on the common stock of a firm, $R_{i t}$. Part $\beta_{i *} R_{m t}$ is due to the market, and part $a_{i}+\varepsilon_{i t}$ is independent of the market. The term $\beta_{i}$ indicates the sensitivity of the firm's stock returns to market fluctuations. The term $R_{m t}$ is representative of the information available at time $t$, which affects the stock returns of all the firms. The term $\varepsilon$ it on the other hand, is assumed to reflect the information available to the market about the specific firm, $i$, at time $t$. Since the parameters, $\alpha_{i}$ and $\beta_{i}$ are unbiased estimates, the estimate of $\varepsilon_{i t}$ is also unbiased but noisy. However, by measuring the effects on event-time portfolios of a large sample of firms, the noise in the estimate of the individual abnormal returns can be reduced.

The event date is the day the lawsuit is announced in the media (or equivalently the day a settlement or judgment is announced) and is noted as the reference day 0 . The event window is from day -1 to (). Data for the daily stock returns for each firm are used over a 230-day interval, day -250 to -21 , to estimate the parameters $a_{i}$ and $\beta_{i}$ in Equation (1). The parameter values are then used to estimate the expected daily stock returns during the event window. Deviations of the actual stock returns recorded in the stock markets from the predicted values in the event window constitute abnormal returns. The abnormal returns are considered the reaction of the market to patent litigation. Abnormal returns for each firm are computed for the event window from day -1 to 0 (Mugryalu 
et al. 1990).

The abnormal return for the security $i$ on day $t$ is computed as

$$
A R_{i t}=R_{i t}-\left(a_{i}+\beta_{i} R_{m t}\right)
$$

The standardized abnormal returns for the firm is stock on day $t$ is:

$$
\mathrm{SAR}_{\mathrm{it}}=\mathrm{AR}_{\mathrm{it}} / \mathrm{s}_{\mathrm{it}}
$$

Where, sit is the standard deviation of the regression residuals.

Then, the standardized cumulative abnormal returns for security $i$ from day $T_{1}$ to $T_{2}$ is calculated as:

$$
\operatorname{SCAR}_{\mathrm{i}}=\sum_{t=T_{1}}^{T_{2}} S A R_{i t} / \sqrt{\left(T_{2}-t_{1}+1\right)}
$$

The mean standardized cumulative abnormal returns (MSCAR) for the sample of firms is given by:

$$
\operatorname{MSCAR}=\frac{1}{N} \sum_{i=1}^{N} S C A R_{i}
$$

To test whether the standardized mean cumulative abnormal return is different from zero, we use the test statistic defined as:

$$
\mathrm{Z}=\sum_{i=1}^{l} S C A R_{i} / \sqrt{(N)}
$$

The SCAR's are assumed to be unit normal in the absence of abnormal returns. Since $\mathrm{Z}$ is also unit normal, it is an appropriate test statistic for the mean cumulative abnormal returns.

The methodology assumes that the commencement of the intellectual property infringement lawsuit or the termination is not anticipated by the market before public announcement. However, if the announcements were anticipated by the market the abnormal stock returns provide a lower bound estimate of the impact of the litigation on the stock returns (Dos Santos et a!. 1993).

\section{DATA COLLECTION}

The study focuses on both groups of firms involved in intellectual property infringement litigation, viz. the firms that are claiming damages for infringement (the plaintiffs) and the target firms of lawsuits (the defendants). The impact on the stock returns are measured around the day litigation commencement 
and subsequently the day the lawsuit is settled or a judgment is made. The use of stock returns as a metric for firm value impacts necessitated that both plaintiff and defendant firms are publicly traded. This narrows the sample of firms that are studied but prevents the possibility of results being skewed by a preponderance of non-publicly traded firms among either type of litigants. This approach has the added advantage of possibly shedding light on whether patent lawsuits are a zero-sum transaction between defendant and plaintiff firms.

Data on intellectual property infringement lawsuits filed and settled are collected over the period between 1984 and 1999 for the study. The data is collected from the LEXIS/NEXIS database. The data is restricted to patent litigation lawsuits filed in the computer and information technology industries (for a total of 165 data points). PR Newswire and Computergram International covered nearly one half of the news stories found on the LEXIS/NEXIS database. The news stories collected from the database were then closely analyzed to identify the real date of the commencement of the lawsuit and the date of termination. Also, news items pertaining to the firms around the event dates were examined to see if any other significant event had taken place that would seriously contaminate the results. We limited our data sample to the ones that match commencement and termination events. Some firms ceased to exist by the time judgment (or settlement) was pronounced and consequently had to be eliminated from our sample. We also had to eliminate some data points because matching settlement dates were not found, litigation was not yet settled, or the stock market data was not yet available from the CRSP database.

\section{RESULTS AND DISCUSSIONS}

In addition to examining the abnormal returns on the event date we measured the abnormal returns during the periods before and after the event dates:

1. Pre-commencement (or Pre-Termination): This event window estimates the abnormal stock returns for the event period -20 to $-2(0$ is the event date). This helps to determine whether there was market recognition of the events leading up to the commencement (or termination).

2. Commencement (or Termination): This event window estimates the abnormal returns in the stocks of the firms due to the occurrence of the event. The event window includes both days -1 and 0 since it cannot be detcrmined whether the news release actually occurred the day before its appearance in the published media. The primary purpose of studying this event is to determine whether the event had information content.

3. Post-commencement (or Post termination): This event window estimates the abnormal returns after the occurrence of the event, i.e., from day +1 to day +20 . An examination of this period helps determine whether there are any lags in the market's assimilation of the new information. 


\section{Impact on Defendant Firms Around the Commencement of Litigation}

The results under this category are summarized in Table 1 . We see that on an average the defendant firms suffered a negative abnormal return of $-2.736 \%$ around the event date (event window: -1 to 0 ), which is statistically significant $(\mathrm{z}=-2.451 ; \mathrm{p}<0.05)$. We also see that the proportion of defendant firms who had negative returns is about 0.62. Also, in the event window (ED -20 to ED -2) leading to the event, there are no statistically significant abnormal returns. However, the abnormal returns for the event window (ED +1 to +20 ) turned out to be significantly negative at the p-value of 0.01 level with a negative abnormal return of $-5.981 \%$. This shows that the commencement of patent-related litigation must have impacted the defendant firms in a negative way even after the commencement day, which in turn means that investors viewed this kind of event as a significant blow to the defendant firms' ability to generate consistent future earnings. In other words, it appears that the commencement of litigation did contain information content and that the market, on average, views a net loss to defendant firms at the time of commencement of intellectual property infringement litigation.

TABLE 1.

Average abnormal returns to the common stock of the defendant firms around the date of commencement of a lawsuit during 1984-1999. Stocks traded on the NYSE, AMEX or NASDAQ. Sample size: 43

\begin{tabular}{c|c|c|c}
\hline $\begin{array}{c}\text { Interval of Trading } \\
\text { days (a) }\end{array}$ & $\begin{array}{c}\text { Average abnormal } \\
\text { returns }\end{array}$ & Proportion negative & Z-Statistic (b) \\
\hline $\begin{array}{c}\text { Pre-Commencement } \\
(\mathrm{ED}-20 \text { to ED -2) }\end{array}$ & $0.059 \%$ & 0.56 & 0.296 \\
\hline $\begin{array}{c}\text { Commencement } \\
(\mathrm{ED}-1 \text { to ED) }\end{array}$ & $-2.736 \%$ & 0.62 & $-2.451^{* *}$ \\
\hline $\begin{array}{c}\text { Post-Commencement } \\
(\mathrm{ED}+1 \text { to ED }+20)\end{array}$ & $-5.147 \%$ & 0.69 & $-3.122^{* * *}$ \\
\hline
\end{tabular}

Note: (a) ED is the commencement date in Event time.

(b) The null hypothesis is that the true cumulative average abnormal return equals zero.

- Two-tailed rest

***: Test statistic is significant at the 0.01 level.

** : Test statistic is significant at the 0.05 level

* : Test statistic is significant at the (0.10 level.

\section{Impact on Plaintiff Firms Around the Commencement of Litigation}

Table 2 indicates that on average the plaintiff firms had a positive abnormal return of $4.394 \%$ around the event date (event window: -1 to 0 ), which is statistically significant $(\mathrm{z}=2.03 ; \mathrm{p}<0.05)$. Also in the event window (ED 
-20 to ED -2) leading up to the event, there are no statistically significant abnormal returns. The same is true in the event window $(E D+1$ to +20$)$ following the event. Thus we can assume that the abnormal returns recorded in the event window (ED -1 to $E D$ ) are due to the announcement of the intellectual property infringement litigation commencement. We see that on average the market perceives a net benefit to plaintiff firms at the time of commencement of intellectual property infringement litigation.

TABLE 2.

Average abnormal returns to the common stock of the plaintiff firms around the date of commencement of a lawsuit during 1984-1999. Stocks traded on the NYSE, AMEX or NASDAQ. Sample sizc: 43

\begin{tabular}{c|c|c|c}
\hline $\begin{array}{c}\text { Interval of Trading } \\
\text { days (a) }\end{array}$ & $\begin{array}{c}\text { Average abnormal } \\
\text { returns }\end{array}$ & Proportion negative & Z-Statistic (b) \\
\hline $\begin{array}{c}\text { Pre-Commencement } \\
\text { (ED -20 to ED -2) }\end{array}$ & $-0.894 \%$ & 0.47 & 0.572 \\
\hline $\begin{array}{c}\text { Commencement } \\
(\text { ED -1 to ED) }\end{array}$ & $4.394 \%$ & 0.40 & $2.029 * *$ \\
\hline $\begin{array}{c}\text { Post-Commencement } \\
\text { (ED +1 to ED }+20)\end{array}$ & $-2.032 \%$ & 0.58 & -1.067 \\
\hline
\end{tabular}

Note: (a) ED is the commencement date in Event time.

(b) The null hypothesis is that the true cumulative average abnormal return equals zero.

- Two-tailed test

***: significant at the 0.01 level; **: significant at the 0.05 level; *: significant at the 0.10 level.

\section{Impact on Defendant Firms Around the Termination of the Litigation}

The results under this category are summarized in Table 3 . We see that on average defendant firms earned a positive abnormal return of $0.89 \%$ around the termination date, which is, however, statistically insignificant ( $z=1.42$ ). Although we can imagine the termination itself could be positive news for the defendants, particularly in terms of reduced uncertainty on the outcome of the lawsuit, termination news did not produce a significantly positive response from investors probably because the stock market had already predicted the outcome of most of the judgments/settlements prior to the announcements and the stock prices of defendants already incorporated the expectation of the market. " It is interesting to note that reaction to the termination announcements is on average not negative, which contrasts with the litigation commencement results that we looked at earlier. This can mean that most of the damage was done at the commencement of litigation for the defendant and the reaction to termination news was primarily based on the discrepancy between investors' expectation of how the outcome would turn out and the actual outcome. 
TABLE: 3.

Average abnormal returns to the common stock of the defendant firms around the date of termination of a lawsuit during 1984-1999. Stocks traded on the NYSE, AMEX or NASDAQ. Sample size: 43.

\begin{tabular}{c|c|c|c}
\hline $\begin{array}{c}\text { Interval of Trading } \\
\text { days (a) }\end{array}$ & $\begin{array}{c}\text { Average abnormal } \\
\text { returns }\end{array}$ & Proportion negative & Z-Statistic (b) \\
\hline $\begin{array}{c}\text { Pre-Termination } \\
(\mathrm{ED}-20 \text { to ED -2) }\end{array}$ & $1.523 \%$ & 0.44 & 0.761 \\
\hline $\begin{array}{c}\text { Termination } \\
(\mathrm{ED}-1 \text { to ED) }\end{array}$ & $0.888 \%$ & 0.46 & 0.957 \\
\hline $\begin{array}{c}\text { Post-termination } \\
(\mathrm{ED}+1 \text { to ED }+20)\end{array}$ & $2.620 \%$ & 0.39 & 1.233 \\
\hline
\end{tabular}

Note: (a) ED is the termination date in Event time.

(b) The null hypothesis is that the true cumulative average abnormal return equals zero.

- Two-tailed test

***: Test statistic is significant at the 0.01 level.

** : Test statistic is significant at the 0.05 level.

* : Test statistic is significant at the 0.10 level.

\section{Impact on Plaintiff Firms Around the Termination of the Litigation}

The results under this category are summarized in Table 4 . We see that on average plaintiff firms had an abnormal return of $+1.752 \%$ around the termination date (event window: -1 to 0 ), which is not statistically significant $(z=1.01)$. Also, neither in the event window (ED -20 to ED -2) leading up to the termination of the litigation nor in the post period (ED+1 to ED +20) do we see significant abnormal returns. This is consistent with the results of defendant firms around the termination dates, which also showed that no significant positive or negative responses existed. This also supports our hypothesis, which predicted that stock markct reactions around termination dates would be less prominent than those on litigation commencement dates.

As we briefly mentioned above, an interesting finding in our test is the non-negative abnormal returns for the defendant firms at the time of termination. It seems that investors were quick to notice bad news by reacting negatively at the time of commencement. The stock investors further penalize the defendant firms even after the commencement of litigation as we can see in the strongly negative abnormal returns for the post-announcement period (ED) +1 to +20 ). They may already have considered the potential costs related with the litigation for defendant firms as soon as the commencement of litigation occurred. Therefore, investors did not have to respond to the actual termination of the litigation in a negative fashion. On the contrary, the average abnormal returns were positive (although not statistically significant) and the proportion of abnormal returns that were negative was only 0.46 . 
TABIE 4.

Average abnormal returns to the common stock of the plaintiff firms around the date of termination of a lawsuit during 1984-1999. Stocks traded on the NYSE, AMEX or NASDAQ. Sample size: 43.

\begin{tabular}{c|c|c|c}
\hline $\begin{array}{c}\text { Interval of Trading } \\
\text { days (a) }\end{array}$ & $\begin{array}{c}\text { Average abnormal } \\
\text { returns }\end{array}$ & Proportion negative & Z-Statistic (b) \\
\hline $\begin{array}{c}\text { Pre-Termination } \\
\text { (ED -20 to ED -2) }\end{array}$ & $0.750 \%$ & 0.40 & 0.489 \\
\hline $\begin{array}{c}\text { Termination } \\
\text { (ED -1 to ED) }\end{array}$ & $1.752 \%$ & 0.51 & 1.012 \\
\hline $\begin{array}{c}\text { Post - termination } \\
(\mathrm{ED}+1 \text { to ED +20) }\end{array}$ & $1.173 \%$ & 0.47 & 0.481 \\
\hline
\end{tabular}

Note: (a) ED is the termination date in Event time.

(b) The null hypothesis is that the true cumulative average abnormal return equals zero.

- Two-tailed test

***: Test statistic is significant at the 0.01 level.

** : Test statistic is significant at the 0.05 level.

* : Test statistic is significant at the 0.10 level.

\section{The Effect of Firm Size on the Stock Prices of Plaintiffs and Defendants}

To explore the size-related effects we tested different regression models for both plaintiff and defendant firms. We gathered, as a proxy for firm size, the total market capitalization information on plaintiffs and defendants at the time of lawsuit commencements (i.e., test window $[-1,0]$ ) from the CRSP database. None of the models tested yielded significant results for the defendant firms. Therefore, we conclude that there are no apparent size related advantages or disadvantages to defendant firms as a result of a litigation. However, we find that the abnormal returns for the plaintiff firms are significantly affected by the size of the firms involved. In Table 5, Regression Model (1) tests the main impact of size of the firms on abnormal returns for plaintiff firms. It shows that larger plaintiff firms experience lower abnormal returns when litigation is initiated, which supports our hypothesis (4a) that small plaintiff firms will gain more value at the time of patent lawsuit commencements than larger plaintiffs. The size of the defendant firm has a non-significant effect on the abnormal returns of the plaintiff firms. Model (2) in Table 5 is a non-lincar predictor model for the abnormal returns and has the strongest adjusted- $\mathrm{R}^{-}$ value $(0.4)$. It shows that the abnormal return for plaintiff firms is non-lincarly positively impacted by the size of the plaintiff firm (due to the positive coefficient of the (plaintiff size) term), and there is a negative interaction component with the size of the defendant firm (negative coefficient of the interaction term). The size of the defendant firm continues to have an insignificant impact. The interaction effect and the non-linear effect may be due to market perceptions of greater staying power in the litigation process, as the size of the litigating firms is larger. 
TABLE 5.

Regression Models for the effect of firm sizes on the abnormal returns of the phaintiff firms at litigation commencement. (values in parenthesis are t-scores; test window is $[-1,0]$ ).

\begin{tabular}{c|c|c}
\hline Independent variables & $\begin{array}{c}\text { Regression Model (1) } \\
\text { Abnret (plaintiffs) }\end{array}$ & $\begin{array}{c}\text { Regression Model (2) } \\
\text { Abnret (plaintiffs) }\end{array}$ \\
\hline Intercept & $.138(0.81)$ & $0.64(0.63)$ \\
\hline Plaintiff size & $-0.043(-2.24) * *$ & $-0.36(-1.88)^{*}$ \\
\hline Defendant Size & $0.027(1.40)$ & $0.13(0.5)$ \\
\hline (Plaintiff size) $*$ (Defendant size) $^{\mathrm{a}}$ & & $-0.03(-2.05)^{* *}$ \\
\hline (Plaintiff size) & & $0.04(3.13)^{* * *}$ \\
\hline (Defendant size) $^{2}$ & & $0.017(0.38)$ \\
\hline Adjusted $\mathrm{R}^{2}$ & .1183 & .40 \\
\hline F value & $3.82 * *$ & $6.54 * * *$ \\
\hline
\end{tabular}

Note: a: Firm size is represented by the natural logarithm of the total market capitalization at a day before event date. *: Significant at $0.1 ; * *$ : Significant at $0.05 ; * *$ : Significant at 0.01 .

\section{Differential Impact of Intellectual Property Infringement Litigation on the Stock Prices of Computer Hardware \& Peripherals vs. other Technology Sectors.}

We have classified both defendant and plaintiff parties into computer vs. other technology IT sectors. Computer sector includes computer hardware and peripherals. Other technology sectors include electronic equipment, semiconductor manufacturing, communications equipment, software and others. In hypothesis 5, we propose that there will be difference of impact on the stock prices of relevant parties at the time of patent-related lawsuit between the firms in computer hardware \& peripherals (computer sectors) and other technology sectors. We define computer sectors that are primarily associated with buying equipment and assembling them as less capital intensive than other technology industries such as semiconductors, telecommunications equipment manufacturing, and software industries in our data sample. There were 36 cases in which the plaintiff, both at the time of commencement and termination, was in the computer sector, while there were 50 cases in which the plaintiff was in the other technology industries. Table 7 shows that the abnormal returns gencrated when the plaintiff was from other technology sectors, although marginally significant, is $5.69 \%$ $(z=1.82, p<0.10)$ during the commencement and termination dates (ED) -1 to 0$)$, whereas there were no statistically significant positive abnormal returns for the case when the plaintiffs were from the computer sector. Also, as Table 8 shows, the difference of average abnormal stock returns between computer hardware \& peripherals and other IT sectors at the time of announcement (test window: $[-1,0])$ proved to be significant at the $<_{0}(0.10$ level. This means 
that the already-discussed results of statistically positive abnormal returns for plaintiff firms at the time of commencement and termination of intellectual property infringement litigation were mostly due to the relatively high abnormal returns for the plaintiffs who were from other technology sectors. Table 6 and Table 7 also suggest that the other technology defendants suffered significantly negative stock returns $(-2.61 \%)$ at the time of litigation commencement and termination, which can be compared to the computer sector where there was no significantly negative impact around the announcements. The difference of average abnormal stock returns between the two sectors was statistically significant $(p<0.05$ level) as Table 7 indicates. These findings justify what we suggested in hypothesis 5; the required capital investments for such industries as semiconductor and telecommunication equipment are usually very large and therefore will make intellectual property infringement litigation more significant to those firms since their whole business often depends almost entirely on one major patented product or technology.

\section{TABLE 6.}

Average abnormal returns to the common stock of the firms in computer hardwate \& peripheral sectors around the announcement date of commencement and termination of a lawsuit during 1984-1999. Stocks traded on the NYSE, AMEX or NASAQ.

A. Plalntiff Firms (Sample Size: 36)

\begin{tabular}{c|c|c|c}
\hline $\begin{array}{c}\text { Interval of Trading } \\
\text { days (a) }\end{array}$ & $\begin{array}{c}\text { Average abnormal } \\
\text { returns }\end{array}$ & Proportion negative & Z-Statistic (b) \\
\hline $\begin{array}{c}\text { Pre-Announcement } \\
\text { (ED -20 to ED -2) }\end{array}$ & $-0.874 \%$ & 0.44 & -0.598 \\
\hline $\begin{array}{c}\text { Announcement } \\
\text { (ED -1 to ED) }\end{array}$ & $1.186 \%$ & 0.46 & 1.616 \\
\hline $\begin{array}{c}\text { Post-Announcement } \\
(E D+1 \text { to ED +20) }\end{array}$ & $-1.317 \%$ & 0.54 & -0.610 \\
\hline
\end{tabular}

B. Defendant Firms (Sample Size: 36)

\begin{tabular}{c|c|c|c}
\hline $\begin{array}{c}\text { Interval of Trading } \\
\text { days (a) }\end{array}$ & $\begin{array}{c}\text { Average abnormal } \\
\text { returns }\end{array}$ & Proportion negative & Z-Statistic (b) \\
\hline $\begin{array}{c}\text { Pre-Announcement } \\
\text { (ED -20 to ED -2) }\end{array}$ & $3.589 \%$ & 0.40 & $1--6.4$ \\
\hline $\begin{array}{c}\text { Announcement } \\
\text { (ED -1 to ED) }\end{array}$ & $0.179 \%$ & 0.42 & 0.166 \\
\hline $\begin{array}{c}\text { Post-Announcement } \\
\text { (ED }+1 \text { to ED }+20)\end{array}$ & $0.915 \%$ & 0.48 & 0.451 \\
\hline
\end{tabular}

Note: (a) $\mathrm{ED}$ is the termination date in Event time.

(b) The null hypothesis is that the true cumulative average abnomal return cyuals zero.

***: significant at the 0.01 kevel; **: significant at the 0.05 kevel; *: significant at the 0.10 level. 
TABLE 7.

Average abnormal returns to the common stock of the firms in other technology sectors around the announcement date of commencement and termination of a lawsuit during 1984-1996. Stocks traded on the NYSE, AMEX or NASDAQ.

A. Plaintiff Firms (Sample Size: 50)

\begin{tabular}{c|c|c|c}
\hline $\begin{array}{c}\text { Interval of Trading } \\
\text { days (a) }\end{array}$ & $\begin{array}{c}\text { Average abnormal } \\
\text { returns }\end{array}$ & Proportion negative & Z-Statistic (b) \\
\hline $\begin{array}{c}\text { Pre-Announcement } \\
\text { (ED -20 to ED -2) }\end{array}$ & $1.042 \%$ & 0.42 & 0.633 \\
\hline $\begin{array}{c}\text { Announcement } \\
\text { (ED - } 1 \text { to ED) }\end{array}$ & $5.693 \%$ & 0.44 & $1.823^{*}$ \\
\hline $\begin{array}{c}\text { Post-Announcement } \\
\text { (ED +1 to ED +20) }\end{array}$ & $0.804 \%$ & 0.50 & 0.368 \\
\hline
\end{tabular}

B. Defendant Firms (Sample Size: 50)

\begin{tabular}{c|c|c|c}
\hline $\begin{array}{c}\text { Interval of Trading } \\
\text { days (a) }\end{array}$ & $\begin{array}{c}\text { Average abnormal } \\
\text { returns }\end{array}$ & Proportion negative & Z-Statistic (b) \\
\hline $\begin{array}{c}\text { Pre-Announcement } \\
(\mathrm{ED}-20 \text { to ED -2) }\end{array}$ & $-2.805 \%$ & 0.65 & $-1.775 *$ \\
\hline $\begin{array}{c}\text { Announcement } \\
(\mathrm{ED}-1 \text { to ED) }\end{array}$ & $-2.611 \%$ & 0.70 & $-2.959 * *$ \\
\hline $\begin{array}{c}\text { Post-Announcement } \\
(\mathrm{ED}+1 \text { to ED }+20)\end{array}$ & $-4.595 \%$ & 0.62 & $-2.899 *$ \\
\hline
\end{tabular}

Notc: (a) ED is the termination date in Event time.

(b) The null hypothesis is that the true cumulative average abnormal return equals zero.

- Two-tailed test

***: Test statistic is significant at the 0.01 level

** : Test statistic is significant at the 0.05 level

* : Test statistic is significant at the 0.10 level

\section{TABIE 8 .}

The t-test of abnormal return difference between computer hardware and peripherals and other technology sectors (test window: $[-1,0]$ )

\section{A. Plaintiff Firms}

\begin{tabular}{c|c|c}
\hline & $\begin{array}{c}\text { Computer hardwarc } \\
8 \text { peripherals }\end{array}$ & $\begin{array}{c}\text { Capital and technology } \\
\text { intensive sectors }\end{array}$ \\
\hline Number of samples & 36 & 50 \\
\hline Average abnormal stock returns & $1.186 \%$ & $5.693 \%$ \\
\hline t-statistic & $1.910(\mathrm{p}<0.10)$ & \\
\hline
\end{tabular}


B. Defendant Firms

\begin{tabular}{c|c|c}
\hline & $\begin{array}{c}\text { Computer harctware } \\
\text { and peripherals }\end{array}$ & $\begin{array}{c}\text { Capital and technology } \\
\text { intensive sectors }\end{array}$ \\
\hline Number of samples & 36 & 50 \\
\hline Average abnormal stock returns & $0.179 \%$ & $-2.611 \%$ \\
\hline t-statistic & $2.163(\mathrm{p}<0.05)$ & \\
\hline
\end{tabular}

\section{CONCLUDING REMARKS}

This paper investigates the economic impact of intellectual property infringement litigation on both plaintiff and defendant firms around the date of commencement as well as the date of termination. To our knowledge, this is the first undertaking to study the economic effects of intellectual property infringement lawsuits in any industry. However, we focus our study on the information technology industry as this industry has been witnessing enormous activity in patent litigation as of late.

Our test results suggest that the news of intellectual property infringement litigation was unfavorably accepted in the stock market for the defendants. This is plausible since the best-case scenario for defendant firms is not to lose in litigation. Even if they eventually get a favorable decision, the expected direct and indirect costs incurred by the litigation must be large enough for the stock market to penalize the defendant firms particularly at the time of commencement and for a short period of time after it. On the other hand, abnormal returns for plaintiff firms at litigation commencement date were significantly positive, while those at termination were not.

We also examined whether the firms in computer and peripheral industries have been influenced more by intellectual property infringement litigation than those in other technology sectors. We found fairly strong support for this hypothesis. As we predicted, the abnormal returns of plaintiff firms in other technology sectors at the dates of commencement and termination did exhibit significant positive returns while plaintiff firms in computer industries did not show statistically positive abnormal returns. We also found support for the defendant firms. The negative returns for the defendants in the other technology sectors were significantly negative both around the commencements and during the 20) days after the conmencement, while those in the computer sector did not suffer any significant negative stock returns during those time periods.

In sum, on average, financial markets view lawsuits in the IT industry as being of merit and not frivolous. This is supported by positive returns for the plaintiff and negative returns for the defendant. The combination of the surge in on-line business with the viability of business process patents will undoubtedly 
add to the significance of patent rights to businesses competing in the information age. With the technological revolution well underway, the business and legal communities may be witnessing only the beginning of the rising tide of patent litigation.

Future research includes the examination of the possibility that certain industry specific trends might be prevalent in intellectual property disputes. Recently, patents (as opposed to copyrights) have become an increasingly popular method of protecting software. The number of applications for software-related patents has increased 350 percent between 1987 and 1995, and the number of patents actually issued has increased four-fold since 1987 (Millonzi and Passannante 1996). Therefore, it would be worthwhile to see if the market behaves in a different manner to litigation announcements in the computer softwate industry. Also, it will be interesting to examine whether specific measures of capital intensity and Research \& Development expenditures have influence on the economic impact of intellectual property infringement litigation. Another intriguing aspect of this study could be that intellectual property infringement lawsuits in the IT industry may not necessarily be value-destroying transactions as the test results of average abnormal stock returns at announcements of lawsuit commencement and termination show that plaintiffs, on average, gained significant value which appears to more than make up for the loss that defendant firms suffered. However, this observation is quite preliminary since there are other aspects that need to be considered. For example, examining actual dollar value of gains and losses as well as long-term stock price performance of the participating firms would be a natural and meaningful extension of this study.

\section{REFERENCES}

Agarwal, G. and W. Kamakura. 1995. The Economic Worth of Celebrity Endorsers: An Event Study Analysis. Journal of Marketing 53(3): 56-62.

Chatterjee, D., V. J. Richardson, and R. W. Zmud. 2001. Examining the Shareholder Wealth Effects of Announcements of Newly Created CIO Positions. MIS Quarterly 25(1): 43-70.

Cockburn, I and Z. Griliches. 1988. Industry Effects and Appropriability Measures in the Stock Market's Valuation of R\&D and Patents. American Economic Review 78(2): $419-423$.

Dang, Z., B. Lev, and F. Narin. Science and Technology as Predictors of Stock Performance, Financial Analysts Joumal 55(3): 20-32.

Dodd, P. and J. B. Warner. 1983. On Corporate Governance: A Study of Proxy contests, Journal of Financial Economics: 401-438.

Dos Santos, B. L., K. Peffers, and D. C. Mauer. 1993. The Impact of Information Technology Investment Announcements on the Market Value of the Firm, 
Information Systems Research 4(1): 1-23.

Ewert, A. 1995. Is IP Litigation in the US Really Worth It?. Managing Intellectual Property' 50: 27-31.

Fama, E. F. 1970. Foundations of Finance, New York: Basic Books Inc.

Gallini, N. T. 1992. Patent Policy and Costly Imitation. RAND Joumal of Economics 23(1): 52-63.

Gallini, N. T. and B. D. Wright. 1990. Technology Transfer under Asymmetric Information. RAND Journal of Economics 21(1): 147-160.

Gilbert, E. 1994. Intellectual property infringement Suit Spur Plan Development. National Underuriter 98(6): 17.

Gilbert, R. and C. Shapiro. 1990. Optimal Patent Length and Breadth. RAND Journal of Economics 21(1): 106-112.

Horstmann, I., M. M. Glenn, and S. Alan. 1985. Patents as Information Transfer Mechanisms: To Patent or (May be) Not to Patent. Journal of Political Economy 93(5): 837-858.

Harter, J. F. R. 1994. The Propensity to Patent with Differentiated Products. Southern Economic Journal 61(1): 195-201.

Im, K. S., K. E. Dow, and V. Grover. 2001. A Reexamination of IT Investment and the Market Value of the Firm-An Event Study Methodology. Information Systems Research 12(1): 103-117.

Jacobson, C. K. 1994. Investor response to health care cost containment legislation: Is American health policy designed to fail?. Academy of Management Journal 37(2): $440-452$.

Jaffe, A. B. 1986. Technological Opportunity and Spillovers of R\&D: Evidence from Firms' Patents, Profits and Market Value. American Economic Review, 76(5): 984-1001.

Klemperor, P. 1990. How Broad Should The Scope of Patent Protection Be?. RAND Jounnal of Economics 21(1): 113-130.

Lanjouw, J. O. and M. Schankerman. 2001. Characteristics of Patent Litigation: A Window on Competition. 32(1): 129-151.

Lerner, J. 1994. The Importance of Patent Scope: An Empirical Analysis. RAND Journal of Economics 25(2): 319-333.

Loderer, C., D. C. Mauer. 1992. Corporate Dividends and Seasoned Equity Issues: An Empirical Investigation. Journal of Finance 47(1): 201-225.

loh, L. 1993. The economics and Organization of Information Technology Governance: Sourcing Strategies for Corporate Information Infrastructure, $\mathrm{Ph}$. 1). Thesis, $M I T$.

Manfredi, L. M., M. Ross, and M. David. 1989. The Case of Permissive Patents.

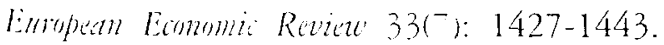

Aeurer, M. J. 1989. The Settlement of Patent Litigation. RAND Jommal of Ecommica 20(1): 77-91.

Millonzi, K. and W'. Passannante. 1996. Beware of the Pirates: How to Protect 
Intellectual Property. Risk Management 43(8): 39-42.

Muoghalu, M. I., H. D. Robinson, and J. L. Glascock. 1990. Hazardous Waste Lawsuits, Stockholder Returns, and Deterrence. Southern Ecrmomic Journal 57(2): 357-370.

Nayyar, P. R. 1995. Stock Market Reactions to Customer Service Changes, Strategic Management Journal 16(1): 39-53.

Nordhaus, W. 1969. Invention, Growth, and Welfare. Cambridge, Mass., MIT Press.

Pakes, A. 1986. Patents as Options: Some Estimates of the Value of Holding European Patent Stocks. Econometrica 54(4): 755-784.

Pearson, J., J. Nickson, and S. Marvel. 2001. Court in Session: Intellectual Property at Risk. Risk Management 48(2): 10-15.

Porter, M. 1980. Competitive Strategy. Free Press, New York.

Rutter, N. 1993. The Great Patent Plague. Forbes: 58-66.

Shapiro, D. M. and N. S. Lorne. 1993. The Stock Market Response to Changing Drug Patent Legislation: The Case of Compulsory Licensing in Canada. Managerial Decision Economics 14(3): 247-259.

Smyth, D. J., J. M. Samuels, and J. Tzoannos. 1972. Patents, Profitability, Liquidity and Firm Size. Applied Economics 4(2): 77-86.

Subramani, M., and E. Walden. 2001. The Impact of E-commerce Announcements on the Market Value of Firms. Information Systems Researib 12(2): 135-154. Tirole, J. 1988. Theory of Industrial Organization. MIT Press.

Vishwasrao, S. 1994. Intellectual Property Rights and the Mode of Technology Transfer. Journal of Developmental Economics 44(2): 381-402.

White, A. P. 1980. The Dominant Firm: A study of Market Power, UMI Research Press.

Wier, P. 1983. The Costs of Antimerger Lawsuits: Evidence from the Stock Market. Journal of Finanial Economics 11(1-4): 207-224. 


\section{Appendix 1. Intellectual Property Infringement Lawsutts in the It Sector DURING 1984-1999*}

\begin{tabular}{|c|c|c|c|c|c|}
\hline Plaintiff & $\begin{array}{c}\text { COM or } \\
\text { NONCOM** }\end{array}$ & Defendant & $\begin{array}{c}\text { COM or } \\
\text { NON-COM }\end{array}$ & $\begin{array}{c}\begin{array}{c}\text { Date of } \\
\text { commencement }\end{array} \\
\end{array}$ & $\begin{array}{c}\text { Date of } \\
\text { termination }\end{array}$ \\
\hline Digital Biometrics & 1 & Identix & 1 & $31-$ May-95 & 09-Jul-98 \\
\hline Thorn EMI & 1 & $\begin{array}{c}\text { Intel, AMD } \\
\text { Microelectronics*** }\end{array}$ & 1 & 06-Apr-95 & 28-May-96 \\
\hline Compaq & 0 & Packard bell & 0 & $28-N o v-94$ & 24-Jul-95 \\
\hline AMD & 0 & Altera & 1 & 16-Aug-94 & 07-Apr-99 \\
\hline Stac & 1 & Microsoft & 1 & 17-Jan-92 & $23-$ Feb- 94 \\
\hline Qualcomm & 1 & Interdigital & 0 & 09-Jul-93 & 13-Sep-94 \\
\hline Qualcomm & 1 & Motorola & 1 & 05-Mar-97 & 06-Nov-97 \\
\hline Qualcomm & 1 & Motorola, Safeco Insurance & 1 & 24-Sep-97 & 13-Jan-99 \\
\hline GTE Wireless & 1 & Qualcomm & 1 & 29-Jun-99 & 13-Dec-99 \\
\hline Access Solutions Int. & 1 & Data/Ware Dev., Kodak & 0 & 29-Aug-97 & 10-Nov-99 \\
\hline Texas Instruments & 0 & Micron Technologies & 0 & (0)-Sep-92 & 16-Jun-93 \\
\hline Intel & 1 & Cyrix & 1 & 27-Mar-92 & 24-Jan-94 \\
\hline Dacapoint & 0 & Vtel & 1 & $22-O c t-93$ & 28-Apr-97 \\
\hline Odetics & 0 & Storagetek & 0 & 29-Jun-95 & 22-Mar-96 \\
\hline Interdigital & 0 & Oki America, Qualcomm & 1 & 16-Apr-93 & 16-Feb-94 \\
\hline Conner Pheripherals Inc. & 0 & Western Digital & 0 & $08-M a r-93$ & 16-Aug-93 \\
\hline Acuson & 1 & Hewlett-Packard & 0 & $04-\mathrm{Mar}-93$ & (05-May-93 \\
\hline Thorn EMI & 1 & Micron Technology & 0 & $20-$ Nov- 92 & $03-N_{0}$ v-93 \\
\hline Rodime plc & 0 & Seagate & 0 & $25-F e b-97$ & 03 -Jul-97 \\
\hline Fluke & 1 & Talon Instruments & 1 & 13-May-88 & 26-May-92 \\
\hline Intel & 1 & Chips and Technologies & 0 & $28-\mathrm{F} \in \mathrm{b}-92$ & $08-\mathrm{Fcb}-93$ \\
\hline Quantum & 1 & Tandon & 1 & $15-5 c p-88$ & $04-\mathrm{Mar}-92$ \\
\hline Xilinx & 1 & Actel Corp. & 1 & $09-$ Mar-92 & $05-$ May- 93 \\
\hline Chips and Technologies & () & OPTi computer & 0 & $17-J u n-91$ & $18-A u g-92$ \\
\hline Archive Corp & 1 & Rexon, Wangtek, Tecmar & 0 & $10-S e p-91$ & $22-5$ un- 92 \\
\hline Digital & 0 & Micro Technology Inc & 1 & $18-5$ un-91 & (91-Jul-92 \\
\hline Digital & 0 & Emulex Corporation & 0 & 13-Aug-9) & (0)-1)ec-91 \\
\hline Digital & () & System Industiies & 1 & $26-A p r-89$ & $0=-D(c-9)$ \\
\hline IQ Technologies & 1 & Microsoft & 1 & $30-\mathrm{Jun}-91$ & $30-$ lun-93 \\
\hline Hayes & 1 & Everex Systems, Omnitel & 1 & $06-\mathrm{Mar}-89$ & $25-\mathrm{Jan}-91$ \\
\hline $\mathrm{M}(\mathrm{eros}) \mathrm{Tel}$ & 1 & AT\& $\mathrm{T}$ & 1 & $28-\mathrm{Mar}-90$ & $2 \geq$-Mar-91 \\
\hline Metro Tel & 1 & Harris Corporation & 1 & $25-M a r-9 \mathrm{i}$ & (b) $-3 u 1-93$ \\
\hline Emerson Electric $\mathrm{Co}$. & 1 & Exac Corporation & () & $11-F e b-84$ & $28-541-87$ \\
\hline Silicon systems & 1 & Exar Corp & 1 & 20)-Dec-90 & $22-3$ an -92 \\
\hline Motorola & 1 & Hitachi & () & $18-N(0 v-89$ & 29-Mar-90 \\
\hline $\mathrm{Tl}$ & 0 & Dell Computer Corp & () & $13-S \cdot p-90$ & $08-M a r-93$ \\
\hline International Rectifier & 0 & Harris & 1 & $30-\mathrm{J} u\}-90$ & $10-\mathrm{F}(\mathrm{b}-\mathrm{t}) 2$ \\
\hline Infernational Rectifier & 0 & Siliconix & 1 & $27-J u n-86$ & (19)-Apr-y) \\
\hline $\begin{array}{l}\text { Information } \\
\text { incernational } \mathrm{lm}\end{array}$ & 1 & Adobe Systems, Apple & 1 & $25-M: 13-89$ & $n^{-}-(b-9) i$ \\
\hline (): (1) & 0 & Siny & 1 & 19)-M1+y-89 & $(\because 1-\lambda)(p-4)$ \\
\hline$\therefore$ Sirten Teloum In & 1 & Dacaposint Corn & 1 & (1) - [ui-s? & $11-5 y p-58$ \\
\hline Varian dssociares Ine & 1 & Materials Rescarch Corp & 1 & 1. + -Aug-is & $1^{-}$. Natr-ss \\
\hline Dikital & 0 & EMC & 1 & $28-11+1-85$ & $115-()+1-5)$ \\
\hline
\end{tabular}

Note: : : The sample only includes the lawsuits in which information on both commencement and termination dates were available.

:s: : 0 if a firm is in the computer hardware and peripheral sectors, and $f$ if a firm falls into other technology category $\cdots$.

**: If dere were multiple partics of defendants or plaintiffs, the total abnormal returns of these firms were used. 


\section{ENDNOTES}

${ }^{1}$ Patent and Trademark Office Review, 1998.

2 The average cost to litigate a patent case today is $\$ 2.5$ million, and each year that increases 10 to 15 percent. In light of the amounts at stake, law firms and plaintiffs treat Intellectual Property (IP) litigation as a growth industry (Pearson, Nickson and Marvel, 2001).

3 Electronic Business Buyer. 1994. 20(4): 38.

4 The Court of Appeals of the Federal Circuit (CAFC) was established in order to decide appeals on all patent cases regardless of the district court from which the case originated. The objective was to create a coherent body of patent law in the hope that this would encourage greater investment in technology. Prior to the CAFC, the appeal of a patent case could go to any one of 10 different circuit courts of appeal which would also be handling criminal cases, admiralty cases, bankruptcy cases, etc. Decisions by thedifferent courts were often confusing and inconsistent.

5 Barrons. 1994. 74(11): 17.

${ }^{6}$ This explanation is plausible if we consider the time gap between the announcement and termination of this type of litigation is usually two to five years. 